\title{
Accounting
}

\section{Liquidity variations and variability cohesiveness with revenue and profitability: A case of Saudi energy sector companies}

\author{
Anis Ali ${ }^{\mathbf{a}^{*}}$
} \begin{abstract}
A B S T R A C T
Liquidity refers to the paying ability of the business organization while profitability assesses the profit earning capacity of the business organization. The liquidity of the business organization can be bifurcated into two based on time i.e., short-term and long-term liquidity. The short-term liquidity reveals the operational efficiency while long-term liquidity refers to the financial capability to repay the long-term debts of the business organization. The short-term paying ability is the management of the working capital or efficient management of the current assets and current liabilities. The current assets and current liabilities are directly related to the revenue of the business and further affected by the profitability, indirectly. The long-term paying ability or financial health of the business organization is reflected by the debts and equity ratio. The energy sector of Saudi Arabia is a prominent sector and contributes to the economy progressively. The study is based on secondary data and reveals the long-term and short-term liquidity variations and the cohesiveness of long-term and short-term liquidity with the revenue and profitability of energy sector companies. The study reveals the significant variations in the short-term and long-term liquidity and cohesiveness between the revenue, profitability, and short-term and long-term liquidity of the energy sector companies.
\end{abstract}

\section{Introduction}

Liquidity refers to the paying ability while profitability indicates the profit earning capacity of the business organizations. Based on time, the liquidity can be bifurcated into two categories i.e., short-term and long-term paying ability. The short-term paying ability indicates the paying ability of the business liabilities within an accounting period while the long-term paying abilities refer to the paying abilities of the business liabilities which are payable after the current accounting period. The profitability measures the profit earning capacity of the business organization. The profit earning capacity can be based on the sales volume of funds invested in the business organization. Normally, it is assumed that the revenue or sales volume and profit earning capacity are governed by the funds invested in operational activities or working capital and funds invested in fixed assets, if other things remain constant. The level of investments in the fixed assets and working capital management i.e. management of current assets and current liabilities enhances the level of sales volume while the level of sales volume enhances the absolute amount of the profit but profitability of the business organizations affected by the gap of the sales price and total cost of the product. The revenue and profitability of the business organization are affected by some external and internal factors. The internal factors are controllable while external factors uncontrollable and unpredictable. In Internal factors, operational performance governs the revenue and profit, and profitability. The absolute amount of the profit positively and perfectly correlated with the level of revenue of the business organization. But, profit-earning capacity depends on the manufacturing or

* Corresponding author

E-mail address: ah.ali@psau.edu.sa (A. Ali) 
administrative efficiencies and sale price of the product which is governed by the behavior of the buyer in the market, ultimately. The energy sector of Saudi Arabia is the prominent sector of Saudi Arabia and contributes progressively to the economy. It is evident that in the last few years the revenue and profitability of the energy sector companies of Saudi Arabia are fluctuating. It is assumed that the working capital management or short-term liquidity and capital structure or long-term paying ability governs the revenue and profitability of the energy sector companies of Saudi Arabia.

\section{Literature Review}

Bhunia and MuKhuti (2011) explained that the management of current assets and current liabilities creates the balance between profitability and liquidity and means to maintain the cohesiveness between the profit earning capacity and paying ability. Alagathurai (2013) and Aminu (2012) found that profitability and liquidity vary positively in trading companies of Saudi Arabia. This indicates the variability cohesiveness between liquidity and profitability while Priya and Nimalathasan (2013) suggested the optimum balance between liquidity and profitability. Ben-Caleb et al. (2013) advocated maintaining the optimum level of liquidity as the extreme level is not positive for profitability. This indicates the negativity variability and cohesiveness of profitability and liquidity. Ehiedu (2014) found the positivity in cohesiveness between the positivity and liquidity and advocated an optimum balance between profitability and liquidity for the smooth operation of business activities. There are some other factors that also govern the profitability of the business organization. Khan and Khokahr (2014) revealed that operational performance governs the profitability of the petrochemical companies in Saudi Arabia. Rehman, et al. (2015) studied companies listed in the Saudi stock exchange and Return on Assets and Return on Equity studied to get the profit earning capacity. The current ratio, liquidity ratio, and absolute liquidity ratio measured the short-term paying capacity of listed companies in Saudi Arabia and found no co-variability and cohesiveness between the profitability and liquidity. Kumar et al. (2016) suggested that the effective management of working capital enhances profitability. This impliedly refers to the positivity and cohesiveness between liquidity and profitability. Al-Shuaibi et al. (2016) investigated and found that external factors like competitiveness and innovation enhance the financial performance of the business organization. Sinha et al. (2016) explored the positivity between cash management and profit earning capacity and indicated the positive variability and cohesiveness of profitability and liquidity. Akhtar \& Asif (2017) explored that the operational efficiencies and utilization of the resources enhance the performance of the business organization and suggested the operational activities at a larger scale to achieve profitability growth. Ali and Abu Theeb (2018) explored that the cost factor affects the profitability of the business organization. Panigrahi et al. (2018) found the negative co-variability or cohesiveness between the profitability and liquidity in Indian companies and explored the varied relationship from organization to organization (Panigrahi, 2019). Pushparaj and Pimplapure (2019) found the positivity in cohesiveness in between the short-term and long-term liquidity and profitability in Indian pharmaceutical companies. Farhan et al. (2019) indicated that corporate governance plays a vital role in maintaining the liquidity and profitability of Indian pharmaceutical companies. Sodha (2020) revealed the negativity between the liquidity and profitability of the business organizations. Above all studies explain the relationship between profitability and liquidity and suggested maintaining an optimum level of liquidity for the smooth operation of business activities. There is no study available to explain the similarity in profitability and liquidity in the context of revenue or turnover profitability of energy sector companies of Saudi Arabia. The present study tries to find out the similarity of revenue and gross profitability, and factors of short-term and longterm liquidity of energy sector companies of Saudi Arabia. The study also analyzes the cohesiveness and level of cohesiveness between the revenue, profitability, and factors of short-term and long-terms liquidity. To fulfill the research gap following hypotheses can be framed:

\subsection{Research Hypotheses}

To analyze the liquidity based on revenue and investment, hypotheses can be divided into two categories:

$\mathrm{H}_{01}$ : There is an insignificant difference between the operational liquidity, and financial liquidity of energy sector companies of Saudi Arabia.

$\mathrm{H}_{02}$ : There is no cohesiveness between the revenue, gross profitability, and operational liquidity and financial liquidity of energy sector companies of Saudi Arabia.

\section{Research Methodology}

The analysis is based on the secondary data extracted from the websites of the energy sector companies of Saudi Arabia for the period 2012 to 2019. Saudi electricity Co. (SECO.), Aldarees, Petro Rabigh, and the national Shipping Corporation of Saudi Arabia (BAHRI) companies are considered for the study to analyze the liquidity, revenue, and investment. The liquidity of the companies is measured by the financial ratios (Ali \& Haque, 2014). Liquidity measurement bifurcated into two categories:

A. Operational Liquidity

$$
\text { Current Ratio }(\mathrm{CR})=\frac{\text { Current Assets }}{\text { Current Liabilities }}
$$


B. Financial Liability

Debt-Equity Ratio (D/E Ratio) $=\frac{\text { Debt or Long term loans }}{\text { Equity }}$

ANOVA (Analysis of Variance) is applied to know the significance in similarity of profitability of energy companies of Saudi Arabia (Ali, A., 2020a).

$\mathrm{F}=\frac{B s s / d f 1}{W s s / d f 2} ;$ While, $\mathrm{F} \geq \mathrm{F} \propto$, Reject $\mathrm{H}_{0}$

Karl Pearson's Correlation is applied to get the relationship between the operational liquidity, financial liquidity, and revenue and the total investment or total resources (Ali, 2020b). To know the long-term and short-term cohesiveness between the revenue and current assets, current liabilities, and revenue and debt, equity Fixed based Index numbers (FBI) and Chain Based Index numbers $(\mathrm{CBI})$ calculated:

$\mathrm{FBI}=\frac{V c y}{V b y} * 100 ;$ and

$\mathrm{CBI}=\frac{V c y}{V p y} * 100$

$\mathrm{Vcy}=$ Value in current year, $\mathrm{Vby}=$ Value in base year, and $\mathrm{Vpy}=$ Value in previous year.

The correlation between the index numbers of the variables explains the level of mutual cohesiveness.

\section{Analysis}

To attain the objectives of the study, the analysis can be bifurcated into two categories:

I. Liquidity Variations in energy sector companies of Saudi Arabia

II. Variability Cohesiveness between revenue and factors of operational liquidity and financial liquidity

\subsection{Liquidity Variations in energy sector companies of Saudi Arabia}

The significant variation in the liquidity reflects the unequal paying ability of the energy sector companies of Saudi Arabia. The paying ability is measured according to the time i.e. short-term and long-term paying ability. To measure the variations in the liquidity, the hypothesis can be divided into two categories:

$\mathrm{H}_{0} 1.1$ : There is an insignificant difference among the operational liquidity of energy sector companies of Saudi Arabia. $\mathrm{H}_{0} 1.2$ : There is an insignificant difference among the financial liquidity of energy sector companies of Saudi Arabia.

\subsubsection{Variations in short-term paying ability}

The short-term paying ability reflects the ability to pay the short-term liabilities or liabilities that are payable within one year or within the accounting period. So, short-term paying ability is measured by establishing the relationship between the current assets and current liabilities.

\section{Table 1}

Short-term paying ability (Current Ratio) of the energy sector companies of Saudi Arabia

\begin{tabular}{|c|c|c|c|c|}
\hline Years & Aldarees Co. & SECO. & Petro rabigh & BAHRI \\
\hline 2012 & 0.914 & 0.686 & 1.009 & 1.109 \\
\hline 2013 & 0.821 & 0.885 & 1.036 & 1.053 \\
\hline 2014 & 0.856 & 0.878 & 1.107 & 0.386 \\
\hline 2015 & 1.031 & 0.618 & 0.724 & 1.545 \\
\hline 2016 & 0.876 & 0.472 & 0.847 & 1.886 \\
\hline 2017 & 0.810 & 0.255 & 0.919 & 1.802 \\
\hline 2018 & 0.538 & 0.271 & 0.588 & 1.603 \\
\hline 2019 & 0.633 & 0.326 & 0.412 & 1.549 \\
\hline Mean & 0.810 & 0.549 & 0.830 & 1.367 \\
\hline$\sigma$ & 0.156 & 0.257 & 0.240 & 0.494 \\
\hline $\mathrm{CV}$ & 0.192 & 0.468 & 0.289 & 0.367 \\
\hline
\end{tabular}

Source: Author's own calculations based data available in the Balance sheet of the energy sector companies available at companies' website. 
From Table 1 it is obvious that the short-term paying ability of all energy sector companies are not satisfactory as the normally current assets expected two times of the current liabilities. The current assets are the lower than the current liabilities in Aldarees (CR-0.810), SECO. (CR-0.549), and Petro Rabigh (CR-0.830) except the national Shipping Corporation of Saudi Arabia (BAHRI) (CR-1.367). The short-term paying ability of the energy sector companies are poor and companies avail the credit facilities from the suppliers while the recovery from the debtors is stronger comparatively to payment to the creditors. The individual variations in the short-term paying ability in the energy sector companies are insignificant for the period 2012 to 2019 as the coefficient of variation (CV) of all four companies are lesser than 1 . All the companies maintained the low-level liquidity in the period 2012 to 2019 . There is no change in the liquidity strategy of the company or no external factor affected the shortterm paying ability of the energy sector companies. So, the short-term paying ability of the energy sector companies is weaker and there is no significant variation seen in the short-term paying ability for the period 2012 to 2019.

\begin{tabular}{llll}
\hline H. No. & Hypotheses & $\mathrm{F}^{*}$ & $\mathrm{~F} \alpha^{* *}$ \\
\hline $\mathrm{H}_{0} 1.1$ & $\begin{array}{l}\text { There is insignificant difference among the operational liquidity of } \\
\text { energy sector companies of Saudi Arabia. }\end{array}$ & 9.625601 & 2.946685 \\
\hline Source: *F values (ANOVA) calculated based on the current ratio (as given in table 1) and **F taken from the F-table at 5\% level of significance
\end{tabular}

Source: *F values (ANOVA) calculated based on the current ratio (as given in table 1 ) and **F taken from the F-table at $5 \%$ level of significance.

The above ANOVA study of the short-term liquidity measures reveals that there are significant differences in the short-term paying ability of the energy sector companies of Saudi Arabia. Probably, this indicates that there is a difference in the recovery from the debtors and payment to the creditors. From the above variability of liquidity and difference of liquidity analysis, it is obvious that the short-term paying ability of the energy sector companies of Saudi Arabia is:

1. Weaker,

2. Stationary, and

3. Mutually significantly different

\subsubsection{Variations in long-term paying ability}

The long-term paying ability reflects the ability to pay the long-term liabilities/ loans/ debts or liabilities which are payable after one year or after the current accounting period. The long-term paying ability is measured by establishing the relationship between the long-term debts or long-term loans and shareholders' equity. This indicates that the owners' equity is enough to redeem the external capital or debts.

\section{Table 2}

Long-term paying ability (Debt-equity Ratio) of the energy sector companies of Saudi Arabia

\begin{tabular}{|c|c|c|c|c|}
\hline Years & Aldarees Co. & SECO. & Petro rabigh & BAHRI \\
\hline 2012 & 0.153 & 0.613 & 2.622 & 0.786 \\
\hline 2013 & 0.186 & 0.653 & 2.304 & 0.749 \\
\hline 2014 & 0.159 & 0.884 & 1.941 & 0.531 \\
\hline 2015 & 0.127 & 0.948 & 4.122 & 0.774 \\
\hline 2016 & 0.054 & 0.984 & 4.487 & 0.661 \\
\hline 2017 & 0.262 & 0.736 & 3.650 & 0.926 \\
\hline 2018 & 0.160 & 0.664 & 2.626 & 0.938 \\
\hline 2019 & 0.069 & 0.713 & 2.354 & 0.867 \\
\hline Average & 0.146 & 0.774 & 3.013 & 0.779 \\
\hline$\sigma$ & 0.066 & 0.144 & 0.941 & 0.137 \\
\hline $\mathrm{CV}$ & 0.450 & 0.186 & 0.312 & 0.176 \\
\hline
\end{tabular}

Source: Author's own calculations based data available in the Balance sheet of the energy sector companies available at companies' website.

From Table 2 it is obvious that the long-term paying ability or financial position of all energy sector companies are very strong except Petro Rabigh (D/E Ratio 3.013). In all the energy sector companies the external funds are lower than the internal capital except Petro Rabigh. In Petro Rabigh, the long-term debts are more than three times the equity capital. The Petro Rabigh company is working on equity and enjoying profitability on the external funds while other companies utilize their internal funds and prefer a low-risk strategy in paying the charges on contractual capital. The individual variations in the long-term paying ability or financial position are insignificant for the period 2012 to 2019. The energy companies of Saudi Arabia utilize their equity to manage the funds to run the business activities and no significant variations in the financial position of the energy sector companies.

\begin{tabular}{llll}
\hline H. No. & Hypotheses & $\mathrm{F}^{*}$ & $\mathrm{~F} \alpha^{* *}$ \\
\hline $\mathrm{H}_{0} 1.2$ & $\begin{array}{l}\text { There is insignificant difference among financial liquidity of energy } \\
\text { sector companies of Saudi Arabia. }\end{array}$ & 11.56426 & 2.946685 \\
\end{tabular}

Source: Author's own calculations based data available in the Balance sheet of the energy sector companies available at companies' website. 
The above ANOVA study of the long-term liquidity measures reveals that there are significant differences in the long-term payment ability of the energy sector companies of Saudi Arabia. Probably, this indicates the varied fund arrangement policies of the energy sector companies of Saudi Arabia. From the above variability of long-term liquidity and difference of liquidity analysis, it is obvious that the long-term payment ability of the energy sector companies of Saudi Arabia is:

1. Strong

2. Stationary, and

3. Mutually significantly different

\subsection{Variability Cohesiveness between revenue, net profit and factors of operational liquidity and financial liquidity}

Based on Liquidity Variations in energy sector companies of Saudi Arabia, three is a difference in the short and long-term paying abilities of the energy sector companies. So, the variability cohesiveness can be studied in two categories i.e. short-term and long-term variability cohesiveness of liquidity in the context of revenue and net profit. To measure the cohesiveness in the liquidity, the hypothesis can be divided into two categories:

$\mathrm{H}_{0}$ 2.1: There insignificant difference among the cohesiveness of operational liquidity of energy sector companies of Saudi Arabia.

$\mathrm{H}_{0} 2.2$ : There insignificant difference among the cohesiveness financial liquidity of energy sector companies of Saudi Arabia.

\subsubsection{Variability Cohesiveness between revenue, net profit and factors of operational liquidity}

The variability cohesiveness between the revenue, net profitability, and current assets and current liabilities explains the governance of the short-term profitability by the current assets and current liabilities. The perfect and high degree correlation between the revenue, net profit, and factors of measurements of short-term liability indicate the higher governance while low degree or no correlation reveals the poor or no governance by the current assets and current liabilities.

Table 3

Long-term and short-term cohesiveness between revenue, net profit and factors of operational liquidity

\begin{tabular}{|c|c|c|c|c|c|c|c|c|c|}
\hline \multirow{2}{*}{\multicolumn{2}{|c|}{$\begin{array}{l}\text { Revenue, profitability and factors of } \\
\text { liquidity }\end{array}$}} & \multicolumn{2}{|c|}{ Revenue } & \multicolumn{2}{|c|}{ Gross profit } & \multicolumn{2}{|c|}{ Current Assets } & \multicolumn{2}{|c|}{ Current Liabilities } \\
\hline & & CBI & FBI & $\mathrm{CBI}$ & FBI & CBI & FBI & $\mathrm{CBI}$ & FBI \\
\hline \multirow{3}{*}{ Revenue } & CBI & 1.00 & & & & & & & \\
\hline & FBI & 0.57 & 1.00 & & & & & & \\
\hline & $\mathrm{CBI}$ & 0.20 & -0.24 & 1.00 & & & & & \\
\hline \multirow[t]{2}{*}{ Gross Profit } & FBI & 0.51 & 0.60 & 0.44 & 1.00 & & & & \\
\hline & CBI & $\underline{0.35}$ & 0.29 & -0.60 & -0.09 & 1.00 & & & \\
\hline \multirow[t]{2}{*}{ Current Assets } & FBI & 0.39 & 0.62 & -0.14 & $\underline{0.52}$ & 0.57 & 1.00 & & \\
\hline & $\mathrm{CBI}$ & $\underline{0.42}$ & -0.30 & $\underline{0.72}$ & 0.42 & 0.01 & 0.07 & 1.00 & \\
\hline Current Liabilities & FBI & 0.50 & 0.67 & 0.22 & $\underline{0.93}$ & 0.15 & 0.77 & 0.31 & 1.00 \\
\hline
\end{tabular}

Source: Author's own calculation and index numbers based on average values of energy sector companies of Saudi Arabia

From Table 3 it can be concluded that the current assets of the energy sector company of Saudi Arabia govern the revenue and gross profit positively and moderately in the long and short-term except for gross profit in short-term. The current assets govern the gross profit of energy sector companies of Saudi Arabia moderately but negatively, exceptionally. Normally, the current liabilities govern the revenue and gross profitability of the energy sector companies positively and moderately except gross profit in long-term. The current liabilities govern the gross profit highly and positively in the long-term. So, Hypothesis H02.1 is rejected.

\subsubsection{Variability Cohesiveness between revenue, net profit and factors of financial liquidity}

The variability cohesiveness between the revenue, net profitability, and debt and equity explains the governance of the longterm profitability by debt and equity. The perfect and high degree correlation between the revenue, net profit, and factors of measurements of long-term liability indicate the higher governance while low degree or no correlation reveals the poor or no governance by the debt and equity. 


\section{Table 4}

Long-term and short-term cohesiveness between revenue, net profit and factors of financial liquidity

\begin{tabular}{|c|c|c|c|c|c|c|c|c|c|}
\hline \multirow{2}{*}{\multicolumn{2}{|c|}{$\begin{array}{l}\text { Revenue, profitability and factors of } \\
\text { liquidity }\end{array}$}} & \multicolumn{2}{|c|}{ Revenue } & \multicolumn{2}{|c|}{ Gross profit } & \multicolumn{2}{|c|}{ Debt } & \multicolumn{2}{|c|}{ Equity } \\
\hline & & CBI & FBI & CBI & FBI & CBI & FBI & CBI & FBI \\
\hline \multirow{3}{*}{ Revenue } & $\mathrm{CBI}$ & 1.00 & & & & & & & \\
\hline & FBI & 0.57 & 1.00 & & & & & & \\
\hline & CBI & 0.20 & -0.24 & 1.00 & & & & & \\
\hline \multirow[t]{2}{*}{ Gross Profit } & FBI & 0.51 & 0.60 & 0.44 & 1.00 & & & & \\
\hline & CBI & -0.63 & -0.74 & $\underline{0.16}$ & -0.66 & 1.00 & & & \\
\hline \multirow[t]{2}{*}{ Debt } & FBI & 0.19 & -0.27 & 0.64 & $\underline{0.46}$ & 0.13 & 1.00 & & \\
\hline & CBI & $\underline{0.22}$ & -0.25 & $\underline{0.64}$ & 0.15 & -0.01 & 0.22 & 1.00 & \\
\hline Equity & FBI & $\overline{0.48}$ & 0.53 & $\overline{0.36}$ & 0.89 & -0.47 & 0.59 & 0.17 & 1.00 \\
\hline
\end{tabular}

Source: Author's own calculation and index numbers based on average values of energy sector companies of Saudi Arabia

From Table 4 it can be concluded that the Debts of the energy sector companies of Saudi Arabia govern the revenue moderately but negatively while gross profit positively and moderately in the long and short-term. Normally, the equity governs the revenue and gross profitability of the energy sector companies positively and moderately except gross profit in long-term. The equity governs the gross profitability highly and positively in long-term. So, Hypothesis H02.2 is rejected.

\section{Discussion}

The energy sector companies of Saudi Arabia maintain a low level of short-term liquidity. Probably, this is possible due to the nature of the energy sector industry. The energy companies maintained their low level of short-term liquidity due to convenient or relaxed policies of the creditors and efficient recovery from the debtors. The long-term and short-term paying ability of the energy sector companies are stationary and mutually and significantly different while the short-term paying abilities of the energy sector companies are weaker but long-term paying abilities are strong. This indicates that the energy sector companies manage their short-term paying liabilities and recovery from debtors strongly while another side refers to manage the funds from the internal sources. There is moderate and positive cohesiveness between the current assets and revenue and gross profit of energy sector companies of Saudi Arabia except for gross profit in the short-term. This refers to some other factors except current assets govern the revenue of the energy sector companies of Saudi Arabia in the short and long-term while gross profitability in long-term only. The level of current assets negatively and moderately gross profitability in short-term. Debts of the energy sector companies of Saudi Arabia governs the revenue moderately but negatively while gross profit positively and moderately in the long and short-term. Normally, the debts are raised after the equity capital to fulfill the requirement of the funds in the business. So, there is no need for additional capital in the energy sector companies, or demand for the product of the energy sector companies is saturated. There is moderate and positive cohesiveness in between equity and revenue and gross profitability of the energy sector companies positively and moderately except gross profit in long-term. This refers to some other factors available except equity that governs the revenue and profitability except gross profitability in long-term.

\section{Conclusion}

Based on above all analysis it can be concluded that the long-term and short-term paying ability of the energy sector companies stationary and mutually significantly different. But the short-term paying ability is weaker while long-term paying ability is strong. Some other factors except current assets, current liabilities, debt, and equity govern the revenue and the gross profitability of energy sector companies of Saudi Arabia. The external capital is not needed in the energy sector companies in Saudi Arabia as it negatively governs the revenue and profitability positively but moderately. Possibly, this is due to low demand or high cost of external capital. The equity capital and the gross profitability positively and highly correlated in long-term and moderately in short-term. This also indicates the overcapitalization or high cost of external capital in energy sector companies in Saudi Arabia.

\section{Acknowledgement}

The author would like to sincerely thank the Deanship of Scientific Research, Prince Sattam Bin Abdulaziz University, Saudi Arabia. 


\section{References}

Akhtar, M. H., \& Asif, M. (2017). Evaluating managerial efficiency of petrochemical firms in Saudi Arabia. Benchmarking: An International Journal, 24(1), 244-256. https://doi.org/10.1108/BIJ-06-2014-005

Alagathurai, A. (2013). A nexus between liquidity \& profitability: a study of trading companies in Sri Lanka. Ajanthan, A.(2013). A Nexus Between Liquidity \& Profitability: A Study Of Trading Companies In Sri Lanka. European Journal of Business and Management, 5(7), 221-237.

Ali, A. (2020a). Financial performance and size determinants: growth trend and similarity analysis of Indian pharmaceutical industry. Humanities \& Social Sciences Reviews 8(4), 547-560.

Ali, A. (2020b). Firm size and solvency in Indian pharmaceutical sector: A relational co-movement analysis. Accounting, 6(7), 1199-1208.

Ali, A., \& AbuTheeb, E. (2018). Financial Performance of Petrochemicals Industry in Saudi Arabia: Pre and Post Global Economic Recession. International Journal of Management Studies, 4(8), 21-29. https://doi.org/10.18843/ijms/v5i4(8)/03

Ali, A., \& Haque, M. I. (2014). Ratio Analysis: A Comparative Study of National Petrochemicals Co. and Sahara Petrochemicals Co. of Saudi Arabia. International Journal of Management Academy, 2(4), 53-61.

Al-Shuaibi, K., Zain, M., \& Kassim, N. (2016). Performance indicators for quality, innovation, and competitiveness: A survey on the Saudi manufacturing sector. International Business Research, 9(2), 99-113. https://doi.org/10.5539/ibr.v9n2p99

Aminu, Y. (2012). A nexus between liquidity/profitability trade-offs for working capital management in Nigerias manufacturing sector. International Journal of Arts and Commerce, 1(6), 55-58.

Ben-Caleb, E., Olubukunola, U., \& Uwuigbe, U. (2013). Liquidity management and profitability of manufacturing companies in Nigeria. IOSR Journal of Business and Management, 9(1), 13-21.

Bhunia, A., Khan, I., \& MuKhuti, S. (2011). A study of managing liquidity. Journal of Management Research, 3(2), 1-22.

Ehiedu, V. C. (2014). The impact of liquidity on profitability of some selected companies: The financial statement analysis (FSA) approach. Research Journal of Finance and Accounting, 5(5), 81-90.

Farhan, N. H., Alhomidi, E., Almaqtari, F. A., \& Tabash, M. I. (2019). Does Corporate Governance Moderate the Relationship between Liquidity Ratios and Financial Performance? Evidence from Indian Pharmaceutical Companies. Academic Journal of Interdisciplinary Studies, 8(3), 144-144.https://doi.org/10.5539/ijbm.v11n8p203

Khan, M. Z. R. M. N., \& Khokhar, I. (2014). Select financial ratios as a determinant of profitability evidence from petrochemical industry in Saudi Arabia. European Journal of Business and Management, 6(6), 187-196.

Kumar, S., Srivastava, P., Sinha, S. K., \& Goyal, R. (2016). A Study of Financial Efficiency and Liquidity Position of Indian Pharmaceutical Industry Special Reference to Cipla Ltd. International Journal of Innovations in Engineering and Technology, 7(1), 702-711.

Panigrahi, C. M. A. (2019). Liquidity and Profitability Relationship and Financial Fallacy. THINK INDIA JOURNAL, 22(10). 704-718.

Panigrahi, C. M. A., Raul, N., \& Gijare, C. (2018). Liquidity and profitability trade-off: A study of Indian pharmaceutical companies. NMIMS Journal of Economics and Public Policy, 3(1). 42-56.

Priya, K., \& Nimalathasan, B. (2013). Liquidity management and profitability: A case study of listed manufacturing companies in Sri Lanka. International Journal of Technological Exploration and Learning, 2(4), 161-165.

Pushparaj Kulkarni, D., \& Pimplapure, V. (2019). An Analytical Study of Profitability of Pharmaceutical Companies in India. Journal of the Gujarat Research Society, 21(16), 50-57.

Rehman, M.Z., Khan, N.M., \& Khokhar, I. (2015). Investigating Liquidity-Profitability Relationship: Evidence from Companies Listed in Saudi Stock Exchange (Tadawul). Journal of Applied Finance \& Banking, 5(3), 159-173.

Sinha, S. K., Goyal, R., Kumar, S., \& Gupta, V. A (2016). Study on Engineering of Cash Management and its impact on Profitability of Indian Pharmaceutical Industry with Special Reference to Cipla Ltd. International Journal of Innovations in Engineering and Technology (IJIET), 6(4), 469-478.

Sodha, S. (2020). A Comparison of Pharma Companies Based on Profitability and Liquidity. Tathapi with ISSN 2320-0693 is an UGC CARE Journal, 19(24), 157-162. 
(C) 2021 by the authors; licensee Growing Science, Canada. This is an open access article distributed under the terms and conditions of the Creative Commons Attribution (CC-BY) license (http://creativecommons.org/licenses/by/4.0/). 